\title{
A strain-, cow-, and herd-specipc bio-economic simulation model of intramammary infections in dairy cattle herds
}

Gussmann, Maya Katrin; Kirkeby, Carsten Thure; Græsbøll, Kaare; Farre, Michael; Hisham Beshara Halasa, Tariq

Published in:

Journal of Theoretical Biology

Link to article, DOI:

10.1016/j.jtbi.2018.04.022

Publication date:

2018

Document Version

Peer reviewed version

Link back to DTU Orbit

Citation (APA):

Gussmann, M. K., Kirkeby, C. T., Græsbøll, K., Farre, M., \& Hisham Beshara Halasa, T. (2018). A strain-, cow-, and herd-specipc bio-economic simulation model of intramammary infections in dairy cattle herds. Journal of Theoretical Biology, 449, 83-93. https://doi.org/10.1016/j.jtbi.2018.04.022

\section{General rights}

Copyright and moral rights for the publications made accessible in the public portal are retained by the authors and/or other copyright owners and it is a condition of accessing publications that users recognise and abide by the legal requirements associated with these rights.

- Users may download and print one copy of any publication from the public portal for the purpose of private study or research.

- You may not further distribute the material or use it for any profit-making activity or commercial gain

- You may freely distribute the URL identifying the publication in the public portal 


\section{Accepted Manuscript}

A strain-, cow-, and herd-specific bio-economic simulation model of intramammary infections in dairy cattle herds

Maya Gussmann, Carsten Kirkeby, Kaare Græsbøll, Michael Farre, Tariq Halasa

PII:

DOI:

Reference:

To appear in:

Received date:

Revised date:

Accepted date:
S0022-5193(18)30190-5

10.1016/j.jtbi.2018.04.022

YJTBI 9437

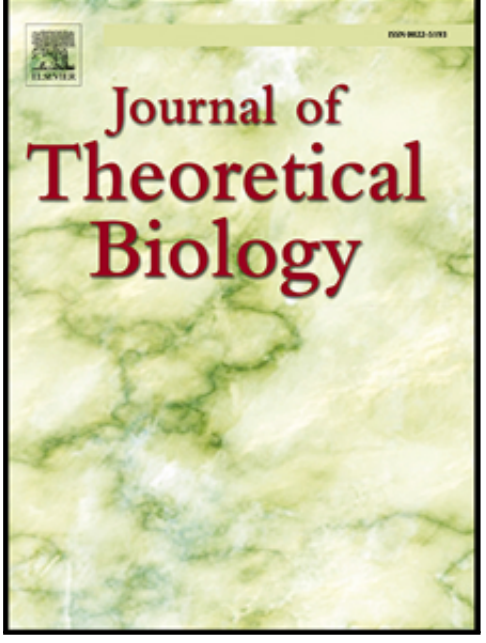

Please cite this article as: Maya Gussmann, Carsten Kirkeby, Kaare Græsbøll, Michael Farre, Tariq Halasa, A strain-, cow-, and herd-specific bio-economic simulation model of intramammary infections in dairy cattle herds, Journal of Theoretical Biology (2018), doi: 10.1016/j.jtbi.2018.04.022

This is a PDF file of an unedited manuscript that has been accepted for publication. As a service to our customers we are providing this early version of the manuscript. The manuscript will undergo copyediting, typesetting, and review of the resulting proof before it is published in its final form. Please note that during the production process errors may be discovered which could affect the content, and all legal disclaimers that apply to the journal pertain. 


\section{Highlights}

- A model with environmental, contagious, and a new opportunistic transmission mode

- Two strains of the same pathogen with different transmission modes are possible

- The model is sensitive to certain parameter changes, proper parameters are necessary

- Can be used for modelling short and long term decisions for mastitis control 


\title{
A strain-, cow-, and herd-specific bio-economic simulation model of intramammary infections in dairy cattle herds
}

\author{
Maya Gussmann ${ }^{\mathrm{a}, *}$, Carsten Kirkeby ${ }^{\mathrm{a}}$, Kaare Græsbølla ${ }^{\mathrm{a}}$ Michael Farre $^{\mathrm{b}}$, Tariq \\ Halasa $^{\mathrm{a}}$ \\ ${ }^{a}$ National Veterinary Institute, Technical University of Denmark, Kemitorvet, Building 204, \\ DK-2800 Kgs. Lyngby, Denmark \\ ${ }^{b}$ SEGES Livestock Innovation, Agro Food Park 15, 8200 Aarhus N. Denmark.
}

\begin{abstract}
\end{abstract}
Intramammary infections (IMI) in dairy cattle lead to economic losses for farmers, both through reduced milk production and disease control measures. We present the first strain-, cow- and herd-specific bio-economic simulation model of intramammary infections in a dairy cattle herd. The model can be used to investigate the cost-effectiveness of different prevention and control strategies against IMI. The objective of this study was to describe a transmission framework, which simulates spread of IMI causing pathogens through different transmission modes. These include the traditional contagious and environmental spread and a new opportunistic transmission mode. In addition, the withinherd transmission dynamics of IMI causing pathogens were studied. Sensitivity analysis was conducted to investigate the influence of input parameters on model predictions. The results show that the model is able to represent various withinherd levels of IMI prevalence, depending on the simulated pathogens and their parameter settings. The parameters can be adjusted to include different combinations of IMI causing pathogens at different prevalence levels, representing herd-specific situations. The model is most sensitive to varying the transmission

\footnotetext{
${ }^{*}$ Corresponding author

Email addresses: makg@vet.dtu.dk (Maya Gussmann), ckir@vet.dtu.dk (Carsten Kirkeby), kagr@dtu.dk (Kaare Græsbøll), mifa@seges.dk (Michael Farre), tahbh@vet.dtu.dk (Tariq Halasa)
} 
rate parameters and the strain-specific recovery rates from IMI. It can be used for investigating both short term operational and long term strategic decisions for the prevention and control of IMI in dairy cattle herds.

Keywords: mastitis, mathematical model, cow-specific, pathogen-specific

\section{Introduction}

Mastitis or intramammary infection (IMI) is one of the most frequent and costly diseases in dairy herds, where costs arise from both milk loss and control 4 measures (Seegers et al., 2003; Halasa et al., 2007). They can be caused by 5 many different pathogens, traditionally differentiated into environmental and 6 contagious. Contagious pathogens are thought to be transmitted during the 7 milking process (Harmon, 1994). They can cause outbreaks, infecting many 8 animals in a short period of time resulting in high incidence rates (Zadoks et al., 9 2001a). In contrast, environmental pathogens are considered to be transmitted, 10 among other things, through reservoirs in the stable and to have an endemic 11 nature, associated with low incidence rates (Zadoks et al., 2001a; Blowey and 12 Edmondson, 2010).

13 Traditionally, Staphylococcus aureus and Streptococcus agalactiae are exam14 ples for contagious pathogens, while Escherichia coli and Streptococcus uberis 15 are considered as environmental. However, Zadoks et al. (2001a) described 16 how $S$. uberis caused an outbreak like situation, suggesting that this particular 17 pathogen strain was transmitted contagiously, indicating that different strains 18 can have different properties. Consequently, control strategies should take the 19 differences (in spread and recovery following treatment) between strains of the same pathogen species into account to be effective. Moreover, some pathogen strains may create reservoirs in the environment and yet express contagious transmission between cows, reflecting an "opportunistic" behavior that combines both contagious and environmental characteristics (Jorgensen et al., 2016). In order to capture this more differentiated behavior, we introduce a new transmis25 sion mode with both contagious and environmental characteristics at the same 

previous bio-economic models.

The objective of this study is to describe a new transmission framework of 54 IMI causing pathogens, including a new opportunistic transmission mode. 


\section{Materials and methods} quarters), and opportunistic (infection probability depends on the number of infected quarters or the presence of bacteria in the environment) transmission on quarter level, cow-specific infection and recovery, and different strains of the 82 same pathogen.

\subsection{Model framework}

This study was conducted with the MiCull model (Mastitis-iCull), version 1.0. The model framework was created by combining an extension of the transmission framework for IMI created by Halasa et al. (2009a) with the iCull simulation model of a dairy herd described by Kirkeby et al. (2016), using R version 3.2 .2 - "Fire Safety" (R Core Team, 2015).

The base iCull model is a stochastic mechanistic bio-economic model that simulates a dairy herd using single-day time steps to allow for both operational and strategic decision making (Kirkeby et al., 2016). In brief, the model simulates a dairy cattle herd in five different physicał herd compartments: calves, heifers, lactating cows, dry cows and calving area. Each cow spends a random (drawn from a given distribution) predefined number of days in each compartment before moving on to the next, with the exception of possible removal from the herd by culling or slaughter decisions (see 2.3). Lactation curves and somatic cell count (SCC) curves are modelled for every cow and depend on cow-specific parameters, indicating the individual level relative to the mean in the herd (Græsbøll et al., 2016). Feeding is dependent on the life stage of each animal, and for lactating cows it is modelled based on the amount of milk produced (Kirkeby et al.,2016).

In the present MiCull model, lactation and SCC curves, as well as farmer decisions, were adjusted to include IMI related factors as described below. The transmission framework for IMI includes environmental (constant infection probability), contagious (infection probability depends on the number of infected

\footnotetext{
(n)
}

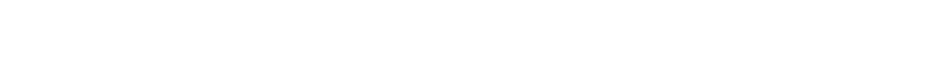



tibility and is thus cow-specific.

In the model, all pathogen strains are identified by a unique strain ID 109 (strain), and active pathogens are marked as such. Infections can occur for 110 all active strains, and the respective infection probabilities $p_{q}^{(\text {strain })}$ are calcu111 lated for all quarters $q$ every day/time step, depending on the transmission 


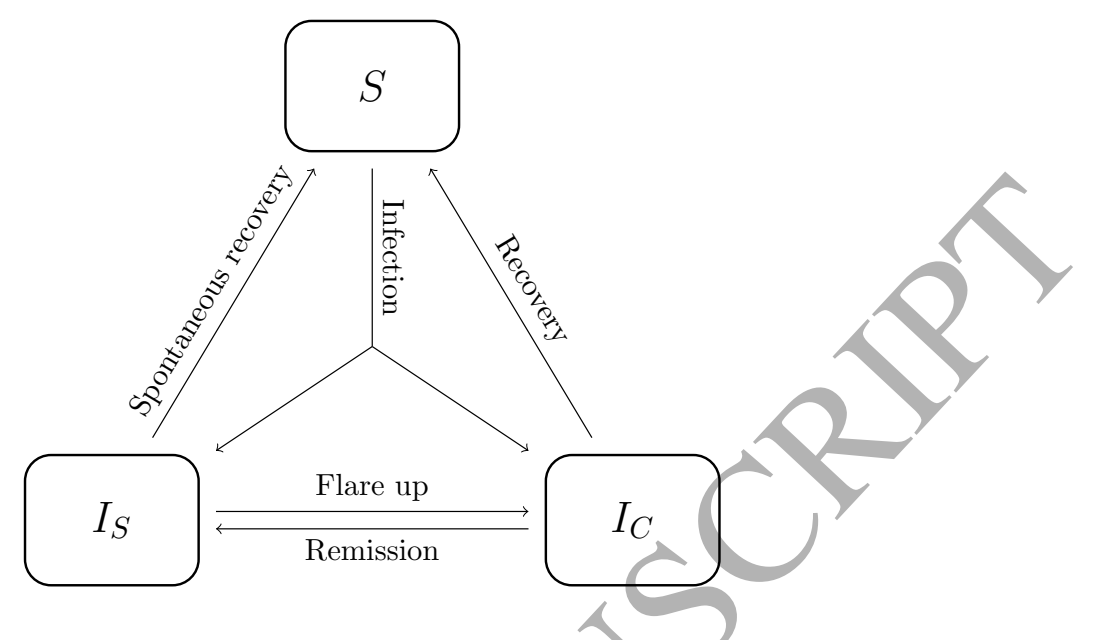

Figure 1: Diagram of the transmission framework used in the simulation model.

112 mode, see equation (1). In the equation, all parameters except the susceptibil-

113 ity factor $\operatorname{Susc}_{q}$ (see 2.2.1) and the total number of quarters $N$ depend on the

114 pathogen strain, which is not specifically notated in (1) for easier readability, it

115 will however be noted in the text (e.g., $\beta^{\text {(strain) }}$ instead of $\beta$ ).

$$
p_{q}^{\text {(strain })}= \begin{cases}1-\exp \left(-\beta \cdot S u s c_{q}\right) & \text { (environmental), } \\ 1-\exp \left(-\beta \cdot \frac{I}{N} \cdot S u s c_{q}\right) & \text { (contagious), } \\ 1-\exp \left(-\beta \cdot \frac{(1-\varepsilon) \cdot I+\varepsilon \cdot \eta \cdot\left(\frac{\sum_{i=1}^{d} 0.01^{i \cdot d^{-1}} \cdot I_{i}}{\sum_{i=1}^{d} 0.01^{i \cdot d}-1}\right)}{N} \cdot S u s c_{q}\right) & \text { (opportunistic). }\end{cases}
$$

$\beta^{(\text {strain })}$ is the transmission rate of that pathogen strain. For environmental strains, the infection probabilities only depend on the respective transmission rates. $I^{(\text {strain })}=I_{S}^{(\text {strain })}+I_{C}^{(\text {strain })}$ (see Figure 1) is the number of quarters (in lactating cows) already infected with a specific pathogen strain at the

120 beginning of the current time step $t_{0}$. A higher number of infected quarters ${ }_{121} I^{(\text {strain })}$, increases the infection probability for contagious and opportunistic 122 strains. $I_{i}^{(\text {strain })}$ is the number of quarters that were infected with a strain 

146 prôbability $P_{c}^{(\text {pathogen })}$ that a new infection will be clinical by another value.

\subsubsection{Dry cows}

For dry cows, IMI will generally be or stay subclinical, except in the first or 149

at the end of time step $t_{0}-i$. It is taken into account in the environmental part of opportunistic transmission, where the pathogen strain decays in the environment for $d^{(\text {strain })}$ days until $1 \%$ of the initial bacteria remain and then disappear. The environmental share is given by $\varepsilon^{(\text {strain })}$, while $\eta^{(\text {strain })}$ is an additional scaling factor for the infectiousness of the strain's environmental part compared to its contagious part. $\theta^{(\text {strain })}$, representing a purely environmental factor (e.g., introduction by humans), allows (re)infection with a strain that is not present in the cows nor the environment of the herd. All parameter values can be found in Table 1.

The probabilities $p_{q}^{(\text {strain })}$ of the active pathogens are combined by

$$
p_{q}^{(\text {total })}=1-\prod\left(1-p_{q}^{(\text {strain })}\right)
$$

and each previously uninfected quarter gets infected with this probability. The infecting pathogens are then drawn according to their relative risk. Infected quarters are allocated to $I_{S}^{\text {(strain) }}$ or $I_{C}^{(\text {strain })}$ depending on the probability $P_{c}^{(\text {strain) }}$ (Table 1).

At each new time step, previously subclinically infected quarters in $I_{S}$ have the chance to flare up or spontaneously recover (Figure 1) with a certain pathogenspecific probability (Table 1). The clinically infected quarters are subjected to a three day treatment (default) with antibiotics, they will thereafter either recover or persist as subclinical cases (remission) (Figure 1). The probability for recovery depends on the causative pathogen and is cow-specific, according to Steeneveld et al. (2011) (Table 1 shows the base probability).

The model includes the possibility to scale transmission rate, flare up probability, and spontaneous recovery probability by any factor, and to replace the last week of the dry period, where clinical IMI can also occur. 


\begin{tabular}{|c|c|c|c|c|}
\hline Parameter & Description & Pathogen & Value & Reference \\
\hline Transmission rate $(\beta)$ & $\begin{array}{l}\text { Rate for susceptible animals } \\
\text { entering subclinical or clinical } \\
\text { state }\end{array}$ & $\begin{array}{l}\text { S. aureus } \\
\text { S. agalactiae } \\
\text { S. uberis (contagious) } \\
\text { S. uberis (environmental) } \\
\text { E. coli }\end{array}$ & $\begin{array}{l}0.0179^{*} \\
0.0068 \\
0.0155^{*} \\
0.0155^{*} \\
0.0001^{*}\end{array}$ & $\begin{array}{l}\text { Zadoks et al. (2002) } \\
\text { Leelahapongsathon et al. (2016) } \\
\text { Zadoks et al. (2001a) } \\
\text { Zadoks et al. (2001a) } \\
\text { Barkema et al. (1998) }\end{array}$ \\
\hline $\begin{array}{l}\text { Probability of clinical } \\
\text { state }\left(P_{c}\right)\end{array}$ & $\begin{array}{l}\text { Probability of entering clinical } \\
\text { state when infected }\end{array}$ & $\begin{array}{l}\text { S. aureus } \\
\text { S. agalactiae } \\
\text { S. uberis (contagious) } \\
\text { S. uberis (environmental) } \\
\text { E. coli }\end{array}$ & $\begin{array}{l}0.17 \\
0.01 * \\
0.32 \\
0.32 \\
0.85\end{array}$ & $\begin{array}{l}\text { Swinkels et al. (2005a) } \\
* * \\
\text { Zadoks et al. (2003) } \\
\text { Zadoks et al. (2003) } \\
\text { Hogan and Smith (2003) }\end{array}$ \\
\hline Flare up probability & $\begin{array}{l}\text { Probability of subclinical } \\
\text { animals going to clinical state }\end{array}$ & $\begin{array}{l}\text { S. aureus } \\
\text { S. agalactiae } \\
\text { S. uberis (contagious) } \\
\text { S. uberis (environmental) } \\
\text { E. coli }\end{array}$ & $\begin{array}{l}0.0081^{*} \\
0.0005^{*} \\
0.0068^{*} \\
0.0068^{*} \\
0.0035^{*}\end{array}$ & $\begin{array}{l}\text { Swinkels et al. (2005a) } \\
* * \\
\text { Swinkels et al. (2005b) } \\
\text { Swinkels et al. (2005b) } \\
\text { Döpfer et al. (1999) }\end{array}$ \\
\hline $\begin{array}{l}\text { Spontaneous recovery } \\
\text { probability }\end{array}$ & $\begin{array}{l}\text { Base probability of spontaneous } \\
\text { cure for subclinical animals }\end{array}$ & $\begin{array}{l}\text { S. aureus } \\
\text { S. agalactiae } \\
\text { S. uberis (contagious) } \\
\text { S. uberis (environmental) } \\
\text { E. coli }\end{array}$ & $\begin{array}{l}0.0064^{*} \\
0.0023^{*} \\
0.0143^{*} \\
0.0143^{*} \\
0.0221^{*}\end{array}$ & $\begin{array}{l}\text { van den Borne et al. (2010b) } \\
\text { Leelahapongsathon et al. (2016) } \\
\text { van den Borne et al. (2010b) } \\
\text { van den Borne et al. (2010b) } \\
\text { van den Borne et al. (2010b) }\end{array}$ \\
\hline Recovery probability & $\begin{array}{l}\text { Probability of recov } \\
\text { clinical animals tha }\end{array}$ & $\begin{array}{l}\text { S. aureus } \\
\text { S. agalactiae } \\
\text { S. uberis (contagious) } \\
\text { S. uberis (environmental) } \\
\text { E. coli }\end{array}$ & $\begin{array}{l}0.4 \\
0.7 \\
0.7 \\
0.7 \\
0.8\end{array}$ & $\begin{array}{l}\text { Steeneveld et al. (2011) } \\
\text { Steeneveld et al. (2011)*** } \\
\text { Steeneveld et al. (2011) } \\
\text { Steeneveld et al. (2011) } \\
\text { Steeneveld et al. (2011) }\end{array}$ \\
\hline$\varepsilon$ & $\begin{array}{l}\text { Environmental share in oppor- } \\
\text { tunistic transmission }\end{array}$ & S. agalactiae & 0.1 & arbitrary \\
\hline$\eta$ & $\begin{array}{l}\text { Scaling factor for infectiousness } \\
\text { of envirommental part in oppor- } \\
\text { tunistic transmission }\end{array}$ & S. agalactiae & 1 & arbitrary \\
\hline$\theta$ & $\begin{array}{l}\text { Purely environmental factor in } \\
\text { opportunistic transmission }\end{array}$ & S. agalactiae & 0 & arbitrary \\
\hline$d$ & $\begin{array}{l}\text { Number of days the bacteria sur- } \\
\text { vive in the environment }\end{array}$ & S. agalactiae & 40 & $\begin{array}{l}\text { arbitrary, more than four weeks } \\
\text { (Jorgensen et al., 2016) }\end{array}$ \\
\hline
\end{tabular}

*rounded values

** S. aureus values were adjusted by the factor by which incidence is different in Barkema et al. (1998).

*** used value of Streptococcus dysgalactiae or uberis

Table 1: Rates and probabilities used in the transmission framework for lactating cows (Figure 1). All parameters are implemented in daily time steps, for all quarters. 
New infections in dry cows can occur for every active strain. Contagious strains are considered active, if at least one quarter of one cow in the herd is infected with that particular strain. Similarly, opportunistic strains are considered active, if they are still present in the herd or if they have a non-zero purely environmental element $\theta^{\text {(strain) }}$. This is important, as the probability of infection is calculated according to

$$
p^{(\text {strain })}=1-\exp \left(-\beta_{d r y}^{(d c t, s t r a i n)}\right)
$$

for every active pathogen strain, where $\beta_{d r y}^{(d r y, s t r a i n)}$ is depending on both the pathogen and whether the cow was treated with dry cow therapy or not (Table 2 ). Note that the infection probability in the dry period is the same for all quarters and not cow-specific. The probabilities of the active pathogens are combined by (2). Each previously uninfected quarter gets infected with this probability. The infecting pathogens are then drawn according to their relative risk. Infected quarters are allocated to $I_{S}^{(\text {strain })}$ or, if the cow is in the first or last week of the dry period, to $I_{S}^{(\text {strain })}$ or $I_{C}^{(\text {strain })}$ depending on the probability $P_{c, d r y}^{(\text {strain) }}$ (Table 2).

Similar to lactating cows, subclinically infected quarters in dry cows can flare up or spontaneously recover (Table 2), however flare up can only happen in the first or last week of the dry period.

Additionally, a cow with a flared up quarter in the first week after dry off will receive dry cow treatment. Dry cow quarters change their status from $I_{C}$ to $I_{S}$ or $S$ after the same number of days as for clinical cases in lactating cows. Here, dry cow treatment influences the probability of recovery for the clinical quarter (Table 2). For clinical quarters in the last week of the dry period, the probability for recovery is calculated similarly as for lactating cows, only without regarding somatic cell count (SCC) and days in milk.

As for lactating cows, transmission rate, flare up probability, and spontaneous recovery probability can be scaled and the probability $P_{c, d r y}^{(\text {strain })}$ that a new infection will be clinical can be replaced. 


\begin{tabular}{|c|c|c|c|c|}
\hline Parameter & Description & Pathogen & Value & Reference \\
\hline $\begin{array}{l}\text { Transmission rate } \\
\left(\beta_{d r y}\right)\end{array}$ & $\begin{array}{l}\text { Rate for susceptible animals } \\
\text { entering subclinical or clinical } \\
\text { state }\end{array}$ & $\begin{array}{l}\text { S. aureus } \\
\text { S. agalactiae } \\
\text { S. uberis (contagious) } \\
\text { S. uberis (environmental) } \\
\text { E. coli }\end{array}$ & $\begin{array}{l}0.0179^{*} \\
0.0011^{*} \\
0.0011^{*} \\
0.0011^{*} \\
0.0001^{*}\end{array}$ & $\begin{array}{l}* * \\
* * * \\
\text { Halasa et al. }(2010,2009 \mathrm{c}) \\
\text { Halasa et al. }(2010,2009 \mathrm{c}) \\
* *\end{array}$ \\
\hline $\begin{array}{l}\text { Transmission rate } \\
\left(\beta_{d r y}^{(d c t)}\right)\end{array}$ & $\begin{array}{l}\text { Rate for susceptible animals } \\
\text { with dry cow treatment entering } \\
\text { subclinical or clinical state }\end{array}$ & $\begin{array}{l}\text { S. aureus } \\
\text { S. agalactiae } \\
\text { S. uberis (contagious) } \\
\text { S. uberis (environmental) } \\
\text { E. coli }\end{array}$ & $\begin{array}{l}0.0005^{*} \\
0.0003^{*} \\
0.0003^{*} \\
0.0003^{*} \\
0.0001^{*}\end{array}$ & $\begin{array}{l}\text { Halasa et al. }(2010,2009 \mathrm{c}) \\
\text { *** } \\
\text { Halasa et al. }(2010,2009 \mathrm{c}) \\
\text { Halasa et al. }(2010,2009 \mathrm{c}) \\
* *\end{array}$ \\
\hline $\begin{array}{l}\text { Probability of clinical } \\
\text { state }\left(P_{c}\right)\end{array}$ & $\begin{array}{l}\text { Probability of entering clinical } \\
\text { state when infected }\end{array}$ & $\begin{array}{l}\text { S. aureus } \\
\text { S. agalactiae } \\
\text { S. uberis (contagious) } \\
\text { S. uberis (environmental) } \\
\text { E. coli }\end{array}$ & $\begin{array}{l}0.1 \\
0.1 \\
0.1 \\
0.1 \\
0.1\end{array}$ & $\begin{array}{l}\text { Halasa et al. (2010) } \\
* * * \\
\text { Halasa et al. (2010) } \\
\text { Halasa et al. (2010) } \\
\text { Halasa et al. (2010) }\end{array}$ \\
\hline Flare up probability & $\begin{array}{l}\text { Probability of subclinical } \\
\text { animals going to clinical }\end{array}$ & $\begin{array}{l}\text { S. aureus } \\
\text { S. agalactiae } \\
\text { S. uberis (contagious) } \\
\text { S. uberis (environmental) } \\
\text { E. coli }\end{array}$ & $\begin{array}{l}0.006^{*} \\
0.0005^{*} \\
0.004^{*} \\
0.004^{*} \\
0.0035^{*}\end{array}$ & $\begin{array}{l}\text { Halasa et al. (2010) } \\
* * \\
\text { Halasa et al. (2010) } \\
\text { Halasa et al. (2010) } \\
* *\end{array}$ \\
\hline $\begin{array}{l}\text { Spontaneous recovery } \\
\text { probability }\end{array}$ & $\begin{array}{l}\text { ontaneous cure } \\
\text { himals }\end{array}$ & $\begin{array}{l}\text { S. aureus } \\
\text { S. agalactiae } \\
\text { S. uberis (contagious) } \\
\text { S. uberis (environmental) } \\
\text { E. coli }\end{array}$ & $\begin{array}{l}0.0079^{*} \\
0.0086^{*} \\
0.0086^{*} \\
0.0086^{*} \\
0.0221^{*}\end{array}$ & $\begin{array}{l}\text { Halasa et al. (2010) } \\
* * * \\
\text { Halasa et al. (2010) } \\
\text { Halasa et al. (2010) } \\
* *\end{array}$ \\
\hline Recovery pro & $\begin{array}{l}\text { Probability of recovery for } \\
\text { clinicalanimals with dry cow } \\
\text { treatment }\end{array}$ & $\begin{array}{l}\text { S. aureus } \\
\text { S. agalactiae } \\
\text { S. uberis (contagious) } \\
\text { S. uberis (environmental) } \\
\text { E. coli }\end{array}$ & $\begin{array}{l}0.77 \\
0.89 \\
0.89 \\
0.89 \\
0.9\end{array}$ & $\begin{array}{l}\text { Halasa et al. }(2010,2009 b) \\
* * * \\
\text { Halasa et al. }(2010,2009 b) \\
\text { Halasa et al. }(2010,2009 b) \\
\text { Halasa et al. }(2010,2009 b)\end{array}$ \\
\hline
\end{tabular}

Table 2: Rates and probabilities used in the transmission framework for dry cows (Figure 1), probability of clinical state, flare up and spontaneous recovery were taken from Halasa et al. (2010), who recalculated them from Bradley and Green (2004) and Green et al. (2005). All parameters are implemented in daily time steps, for all quarters. 


\subsubsection{Heifers} on the fat and protein content. Using the data set described in Kirkeby et al. (2016), we estimated the daily mean protein percentage for all cows, depending 204

Currently, there is no dynamic pathogen transmission in heifers, i.e. cows prior to their first calving. Instead, each pathogen strain has a certain probability to infect heifers (Table 2). These probabilities are added up for the active pathogens to a total probability for heifers to be assigned to $I_{S}$ one day before calving. The pathogens are then drawn depending on their part of the total probability.

\subsection{Production effects and economy}

\subsubsection{Feeding}

Cows are often fed roughage as basic feed plus, concentrate to facilitate a higher milk production. To our knowledge, no stúdies have explicitly estimated the decrease in feed due to IMI. In this model, the feed usage per lactating cow is a function of the energy-corrected milk (ECM) produced, corresponding to $€ 0.1852$ per ECM (following Kirkeby et al., 2016). Therefore, cows with subclinical and clinical IMI automatically have a decreased feed intake because their milk production is decreased, as described below in sections 2.3.3 and 2.3.4. The model also includes an additional option to simulate a farmer who feeds only roughage without concentrate to cows that have their milk withdrawn due to antibiotic treatment, as described in Halasa et al. (2009a). For those cases, a proportion of the feed costs is subtracted to account for lower concentrate usage. By default, however, this option is disabled.

\subsubsection{Milking}

The daily milk yield is calculated for lactating cows (Kirkeby et al., 2016). However, differing from the iCull model, the income from milk is now dependent on days in milk (DIM) and parity $(1,2$ and $3+)$, and fitted a three parameter Wood curve to each cow and parity in the data set (see Græsbøll et al., 2016). Based on the same data set, we estimated distributions for the fat to protein 
234 cow is restricted to $2 \mathrm{~kg}$, which corresponds to the maximal loss in parity $3+$ 235 within the limits of Hortet et al. (1999).

ratio per parity. In the simulation model, each cow is assigned three parameters for the Wood curve to describe the protein percentage and, for each simulated day, the protein content is calculated based on the cow's DIM. A fat to protein ratio is then drawn from the respective distribution for each cow and used to calculate the daily fat yield based on the milk yield and protein percentage.

The income from milk is given by summing the income from fat and protein, withdrawing a milk handling fee based on the daily $\mathrm{kg}$ milk yield and multiplying with a penalty or bonus factor, depending on the bulk tank SCC (Table 3).

\subsubsection{Subclinical IMI}

Subclinically infected animals are subject to an increased SCC. For every subclinical quarter, an increase in the SCC is added to the generic simulated SCC, according to Schepers et al. (1997, Table 1) and Wilson et al. (1997, Table 2, used for scaling missing pathogens). If more than one quarter of a cow is subclinically infected, the maximum increase is added; however, the SCC is cut off at a maximum of 10,000,000 as higher SCC values are rarely observed and for numeric stabilization. The increased SCC in these subclinically infected animals also leads to a higher bulk tank SCC, which is calculated as the weighted mean SCC in the total daily amount of milk produced. The milk price, in turn, is dependent on the bulk tank SCC, as a bulk tank SCC up to 200,000 will result in a $4 \%$ bonus, while a bulk tank SCC above 500,000 will result in the maximal penalty of $10 \%$ (see Kirkeby et al., 2016).

Linked to an increased SCC in subclinically infected cows is milk loss, and as the SCC varies daily for each cow, so does the milk loss. We used the estimates given in Hortet et al. (1999) to reduce the milk yield of each cow with at least one subclinical quarter according to SCC, DIM (except for primiparous cows) and parity (primiparous or multiparous, where we used the estimates for parity 1 or $3+$ cows, respectively), see supplementary Figure S7. The milk loss per 


\begin{tabular}{|c|c|c|c|}
\hline Parameter & Value & Description & Reference \\
\hline $\begin{array}{l}\text { Antibiotic treat- } \\
\text { ment period }\end{array}$ & 3 & $\begin{array}{l}\text { Number of days in antibiotic } \\
\text { treatment, milk from treated } \\
\text { cows is discarded. }\end{array}$ & Steeneveld et al. (2011) \\
\hline $\begin{array}{l}\text { Milk withdrawal } \\
\text { period }\end{array}$ & 6 & $\begin{array}{l}\text { Number of days after antibiotic } \\
\text { treatment where the milk from } \\
\text { treated cows is discarded. }\end{array}$ & $\begin{array}{l}\text { van den Borne et al. } \\
\text { (2010a), Michael Farre } \\
\text { pers. comm. }\end{array}$ \\
\hline $\begin{array}{l}\text { Acute mastitis } \\
\text { probability }\end{array}$ & 0.01 & $\begin{array}{l}\text { Probability for a cow to get acute } \\
\text { mastitis, when it gets clinical } \\
\text { mastitis. }\end{array}$ & Michael Farre pers. comm. \\
\hline $\begin{array}{l}\text { Antibiotic treat- } \\
\text { ment cost }\end{array}$ & $€ 33.3$ & $\begin{array}{l}\text { Cost for antibiotic treatment of } \\
\text { one cow, not including vet visit } \\
\text { or farmer labor. }\end{array}$ & Michael Farre pers. comm. \\
\hline $\begin{array}{l}\text { Dry cow therapy } \\
\text { cost }\end{array}$ & $€ 9.6$ & $\begin{array}{l}\text { Cost for dry cow therapy for one } \\
\text { cow, which includes teat sealants }\end{array}$ & Michael Farre pers. comm. \\
\hline $\begin{array}{l}\text { Opportunity } \\
\text { costs }\end{array}$ & & $\begin{array}{l}\text { Opportunity costs for treatment } \\
\text { of one cow with clinical mastitis. }\end{array}$ & $\begin{array}{l}\text { Halasa et al. (2009a), } \\
\text { Michael Farre pers. comm. }\end{array}$ \\
\hline & $€ 5.8132$ & Price for $1 \mathrm{~kg}$ protein & $\begin{array}{l}\text { www.arla.dk, September } \\
2017\end{array}$ \\
\hline & $€ 4.1519$ & Price for $1 \mathrm{~kg}$ protein & $\begin{array}{l}\text { www.arla.dk, September } \\
2017\end{array}$ \\
\hline $\begin{array}{l}\text { Milk handling } \\
\text { feee }\end{array}$ & $€ 0.0001343$ & Fee for handling $1 \mathrm{~kg}$ milk & $\begin{array}{l}\text { www.arla.dk, September } \\
2017\end{array}$ \\
\hline Culling costs & ca. $€ 500$ & $\begin{array}{l}\text { Costs for culling one cow (price } \\
\text { of a new heifer minus slaughter } \\
\text { value) }\end{array}$ & Huijps et al. (2008) \\
\hline
\end{tabular}

Table 3: Model parameters related to IMI treatment, culling, and milk price. 
60

\subsubsection{Culling}

In the model, culling happens on a weekly basis. If there are more than 200 lactating cows, the farmer will cull the excess number of cows. About half of the culled cows are chosen randomly, those are the cases that have to 

cows with a continuously high SCC, cows with the highest weight for culling.

The costs of culled animals are calculated as the costs for raising a replacement heifer for each cow that is culled (to two years of age, $€ 510$ ), minus the 3 slaughter value the farmer gets for the culled cow (€51). 


\section{tions and outputs were evaluated by mastitis experts. External validation was conducted by comparing model predictions to the literature, as data to validate} 322

The epidemiological model output consists of daily cow level prevalences, as well as the total number of flare ups, remissions, subclinical, and clinical IMI for each simulation. Furthermore, it includes the total number of culled cows due to acute IMI, subclinical IMI and a history of clinical IMI. Culling due to subclinical IMI includes all culled cows with at least one subclinically infected quarter that were prioritized for culling because of a high SCC. To avoid counting a culled cow several times, culling due to the cow having a history of clinical IMI includes only cases in which the cow did not have a high SCC at the last monthly milk yield recording. Cows culled because of acute IMI are counted separately.

The economical model output includes the total milk loss in $\mathrm{kg}$ due to subclinical or clinical IMI (both milk loss and-withdrawal), as well as the total income from milk and the mean milk price penalty percentage (see sections 2.3.2, 2.3.3, and 2.3.4). As the fat and protein percentages for lost milk are not calculated, a mean milk price of around $€ 0.4099$ per $\mathrm{kg}$ is used to calculate costs for milk loss (mean Arla milk price in September 2017). The mean milk price penalty value together with the total income from milk is used to calculate the possible penalty paid due to a high bulk tank SCC. Further economic output includes expenses for treatment of clinical IMI as described above (2.3.4), as well as costs for dry cow therapy (Table 3).

\subsection{Model validation}

Several methods for internal validation were used on the model (Sargent, 2003). Rationalism, including operational graphics: various scenarios were compared to check consistency and credibility of model outputs. Traces: single cows were traced over time to check for consistency. Face validity: model assumpsuch a complicated model is not available.

\subsubsection{Model outputs}


(

\subsubsection{Model convergence}

We tested model convergence on two parameters by simulating 1000 iterations. In a scenario without any IMI causing pathogens, we tested convergence of the energy corrected milk yield (ECM), and in a scenario with three pathogens (using default parameters taken from literature, see Table 1), we tested convergence on the number of clinical cases. In both cases visual inspection showed that 500 iterations were sufficient to obtain stable results (Figure S6). Further visual inspections showed that after five simulated years herd, population, and transmission dynamics were always stable, warranting a five year burn-in period.

\subsubsection{Sensitivity analysis and model runs}

We performed sensitivity analysis on a herd with 200 cows, using 500 simulations of 5 years, with a burn-in time of an additional 5 years. All scenarios were initiated with a $20 \%$ starting prevalence for all pathogen strains, with the exception of environmental strains in multiple pathogen scenarios, where the starting prevalence was set to $10 \%$. These values are arbitrary and were chosen only for presentation of the model

Sensitivity analyses were carried out on the transmission rate $(\beta)$, the spontaneous recovery probability, the probability that a newly infected animal becomes a clinical IMI case $\left(P_{c}\right)$, the flare up probabilities, the environmental part of the opportunistic pathogen $(\varepsilon)$, and the number of days the opportunistic pathogen can survive in the environment $(d)$. For the transmission rate parameter, various scaling factors (all $<1$, except for $E$. coli where factors $>1$ were considered) were considered in the sensitivity analysis; selected values are presented in Table 4. Sensitivity analysis for the spontaneous recovery probability consisted of several scaling factors between 0.25 and 2 . For the other parameters, sensitivity andalyses focused on the actual value instead of the scaling factor: $P_{c}$ and flare up probability were varied between 0.01 and 0.85 and between 0.0002 and 0.02 , respectively. The parameter $\varepsilon$ in opportunistic transmission was varied between 0 and 1 , while $d$ was reduced down to 10 days in increments of 5 days.

To obtain insight into how the model would simulate the dynamics of pathogen 
spread, a great number of scenarios were run in the sensitivity analyses, of which only a few with different transmission rates were selected and presented here.

In the supplementary material, more scenarios were included.

\section{Results}

\begin{tabular}{clccc}
\hline Scenario & \multicolumn{1}{c}{ Pathogens } & $\begin{array}{c}\text { Transmission rate } \\
\text { scaling factor }\end{array}$ & Transmission rate & $\begin{array}{c}\text { Transmission rate } \\
\text { (dry cows) }\end{array}$ \\
\hline \multirow{2}{*}{7} & S. aureus & 0.2 & 0.0036 & 0.0036 \\
9 & S. aureus & 0.1 & 0.0018 & 0.0018 \\
14 & S. agalactiae & 0.55 & 0.0037 & 0.0006 \\
21 & S. uberis (contagious) & 0.8 & 0.0124 & 0.0009 \\
49 & S. aureus & 0.25 & 0.0045 & 0.0045 \\
& S. agalactiae & 0.5 & 0.0034 & 0.0006 \\
56 & S. aureus & 0.25 & 0.0045 & 0.0045 \\
& S. uberis (contagious) & 0.5 & 0.0078 & 0.0006 \\
68 & S. agalactiae & 0.5 & 0.0034 & 0.0006 \\
& S. uberis (contagious) & 0.5 & 0.0078 & 0.0006 \\
& S. uberis (contagious) & 0.5 & 0.0078 & 0.0006 \\
& S. uberis (environmental) & 0.01 & 0.0002 & 0.00001 \\
& S. aureus & 0.25 & 0.0045 & 0.0045 \\
& S. agalactiae & 0.5 & 0.0034 & 0.0006 \\
& S. uberis (contagious) & 0.5 & 0.0078 & 0.0006 \\
& S. uberis (environmental) & 0.01 & 0.0002 & 0.00001 \\
& E. coli & 1 & 0.0001 & 0.0001 \\
\hline
\end{tabular}

Table 4: Selected scenarios. All pathogens start with a $20 \%$ prevalence, except in the five pathogen scenario (98), where the environmental strains start with a $10 \%$ prevalence. Transmission rates are rounded.

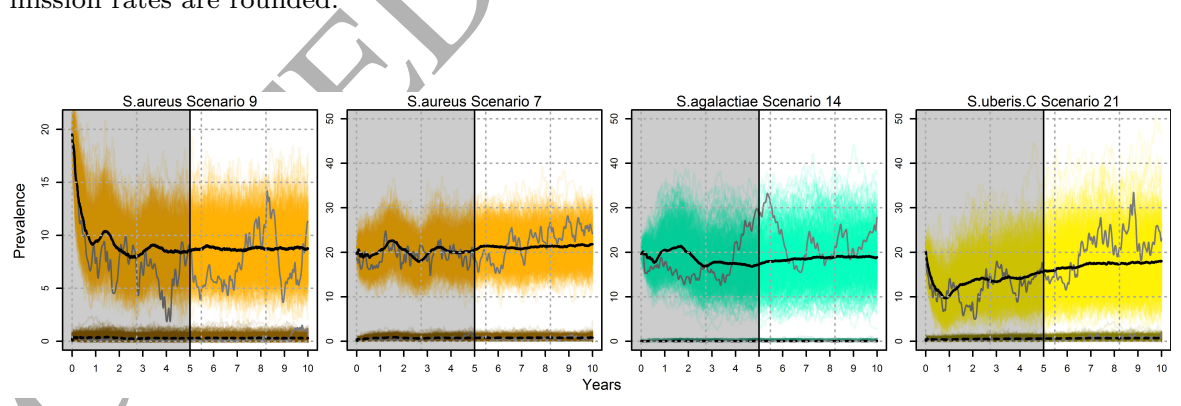

Figure 2: Cow level prevalences in one pathogen scenarios 7, 9, 14, and 21, see Table 4. Every scenario shows smoothed daily prevalences for each of 500 iterations over 5 years with a 5 year burn-in period (with one random iteration displayed in gray), as well as the mean daily prevalence (bold, black). The bottom lines show the daily prevalences of clinical IMI, with the mean displayed as a dashed line. 

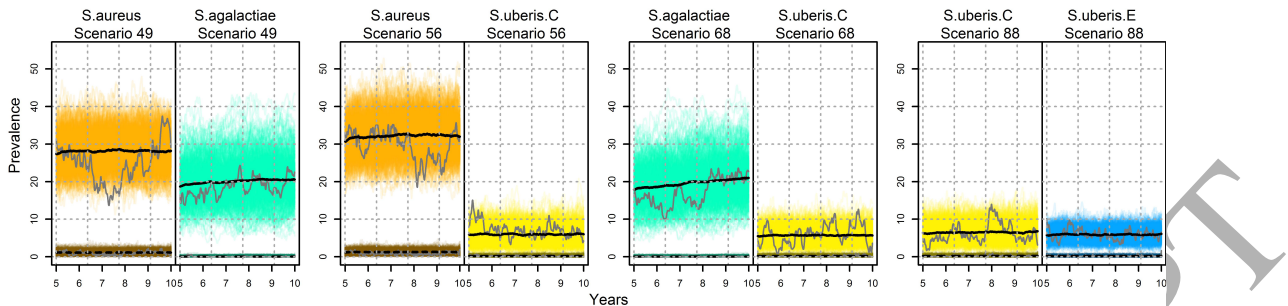

Figure 3: Cow level prevalences in two pathogen scenarios 49, 56, 68, and 88, see Table 4 . Every scenario shows smoothed daily prevalences for each of 500 iterations over 5 years after a 5 year burn-in period (with one random iteration displayed in gray), as well as the mean daily prevalence (bold, black). The bottom lines show the daily prevalences of clinical IMI, with the mean displayed as a dashed line.

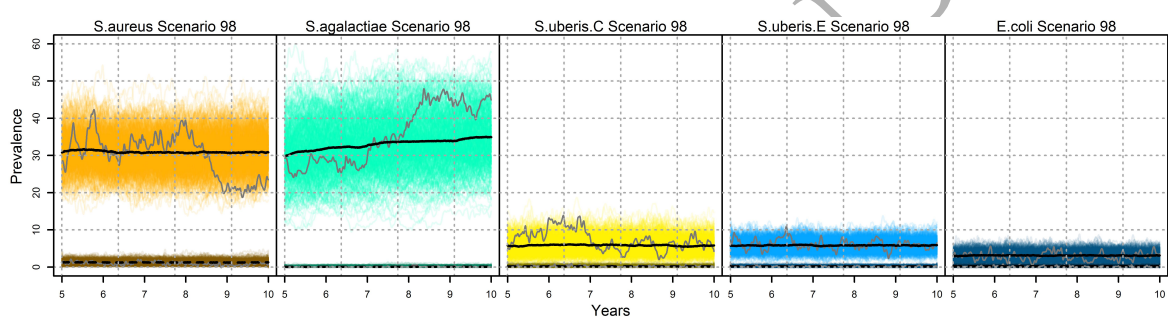

Years

Figure 4: Cow level prevalences in the five pathogen scenario see Table 4, scenario 98. It shows the smoothed daily prevalences for each of 500 iterations over 5 years after a 5 year burn-in period (with one random iteration displayed in gray), as well as the mean daily prevalence (bold, black). The bottom lines show the daily prevalences of clinical IMI, with the mean displayed as a dashed line

The methods used for internal validation showed valid and consistent outcomes of the model in all scenarios. As an illustration, nine scenarios were selected. These include four one pathogen scenarios for different pathogens, four two pathogen scenarios with different pathogen combinations, and one five 361 pathogen scenario with all pathogens (Table 4). Scenarios where exact literature values were used as transmission parameters, led to high prevalences in 3 our setting (results not shown). Therefore, the selected scenarios used adjusted

364 transmission rates, leading to more realistic prevalence estimates (Figures 2, 3, 365 and 4$)$. 
per year (median over 500 iterations and mean over 5 years simulation period); in the multiple pathogen scenarios, numbers are summed over all pathogens.

394 The number of subclinical IMI includes all remission cases, while the number of prevalence is set to $20 \%$, and during the burn-in period it fluctuates depending on the pathogen strain (i.e. the combination of all transmission parameters, see scenarios 7, 14, and 21, Figure 2), or changes depending on the transmission rate (scenarios 9 and 7, Figure 2). After the burn-in period, the prevalence has reached a mostly stable level.

The model also allows coexistence of multiple pathogens or strains, regardless of their transmission mode, on different prevalence levels, depending on the scaling of the transmission parameters (Figures 3 and 4). Scenario 49 and 56 show two pathogen scenarios, where the active pathogen strains are $S$. aureus and $S$. agalactiae or a contagious $S$. uberis, respectively. The transmission rate for $S$. aureus is the same in both scenarios, however the mean daily prevalence is higher in scenario 56, where the second active pathogen is present at a low level. In scenario $68, S$. agalactiae and the contagious $S$. uberis strain are coexisting at similar levels to scenario 49 and 56, respectively. Scenario 88 (Figure 3) shows another scenario with two active pathogen strains, in this case a contagious and an environmental strain of $S$. uberis. Both strains are present at a similar prevalence, with a higher variation for the contagious strain.

Scenario 98 shows a five pathogen, which also includes both a contagious and an environmental strain of S. uberis together with contagious S. aureus, environmental E. coli, and opportunistic S. agalactiae (Figure 4). The contagious strains have the same transmission rate as in the two pathogen scenarios and are at similar daily prevalence levels. The opportunistic S. agalactiae strain also has the same transmission rate as in the two pathogen scenarios, but the prevalence level has increased.

The epidemiological output in Table 5 shows the number of quarter cases clinical IMI includes all flare up cases. Also, one cow may be counted more than one time for the same infection, e.g. if a clinical quarter went into remission and

Figure 2 shows selected scenarios with one active pathogen. The starting 


\begin{tabular}{crlrlrlrl}
\hline Scenario & \multicolumn{2}{c}{ Flare up } & \multicolumn{2}{c}{ Remission } & \multicolumn{2}{c}{ subclinical IMI } & \multicolumn{2}{c}{ clinical IMI } \\
\hline 7 & 120 & $(101,140)$ & 113 & $(95,134)$ & 258 & $(228,293)$ & 134 & $(113,157)$ \\
9 & 44 & $(36,53)$ & 40 & $(32,48)$ & 98 & $(84,112)$ & 47 & $(38,57)$ \\
14 & 7 & $(4,10)$ & 4 & $(2,6)$ & 77 & $(51,107)$ & 8 & $(5,12)$ \\
21 & 78 & $(57,114)$ & 72 & $(49,110)$ & 244 & $(174,363)$ & 149 & $(105,225)$ \\
49 & 172 & $(147,200)$ & 164 & $(138,192)$ & 436 & $(385,498)$ & 196 & $(167,227)$ \\
56 & 221 & $(197,257)$ & 209 & $(186,247)$ & 482 & $(437,551)$ & 264 & $(237,306)$ \\
68 & 33 & $(27,40)$ & 22 & $(17,28)$ & 139 & $(112,171)$ & 46 & $(38,56)$ \\
88 & 58 & $(50,67)$ & 45 & $(37,53)$ & 136 & $(120,156)$ & 94 & $(82,108)$ \\
98 & 261 & $(232,294)$ & 250 & $(221,284)$ & 693 & $(640,752)$ & 370 & $(333,410)$ \\
\hline
\end{tabular}

Table 5: Epidemiological output in median number (with $5 \%$ and $95 \%$ percentiles) of quarter cases per year (mean over 5 years) of the scenarios in Table 4 . Numbers are rounded.

\begin{tabular}{cclllll}
\hline Scenario & \multicolumn{2}{c}{ high SCC } & acute IMI & \multicolumn{2}{c}{ history of IMI } \\
\hline 7 & 22 & $(18,26)$ & 1 & $(0,2)$ & 3 & $(2,4)$ \\
9 & 13 & $(10,16)$ & 0 & $(0,1)$ & 2 & $(1,3)$ \\
14 & 24 & $(19,29)$ & 0 & $(0,0)$ & 0 & $(0,1)$ \\
21 & 15 & $(10,20)$ & 1 & $(0,2)$ & 4 & $(3,6)$ \\
49 & 48 & $(41,55)$ & 1 & $(1,2)$ & 2 & $(1,3)$ \\
56 & 35 & $(30,39)$ & 2 & $(1,3)$ & 3 & $(2,4)$ \\
68 & 27 & $(21,33)$ & 0 & $(0,1)$ & 2 & $(1,3)$ \\
88 & 10 & $(7,13)$ & 1 & $(0,1)$ & 5 & $(3,6)$ \\
98 & 68 & $(60,76)$ & 2 & $(1,3)$ & 2 & $(1,4)$ \\
\hline
\end{tabular}

Table 6: Median number (with $5 \%$ and $95 \%$ percentiles) of culled cases per year (mean over 5 years) of the scenarios in Table 4, see section 2.3.6 for culling categories. Numbers are rounded.

flared up again afterwards. For S. agalactiae, most clinical IMI are flared up subclinical cases and there are few clinical IMI, if the prevalence is at moderate levels (scenario 14). In contrast, the contagious S. uberis strain leads to many more clinical cases, both flared up and directly infected (scenario 21).

Table 6 shows the number of culled cows per year (median over 500 iterations 402 and mean over 5 years simulation period); acutely culled cows, subclinical cows that were culled with a noticeable high SCC, and culled cows with a history of clinical IMI. Most cows that are culled because of IMI related reasons are connected to a high SCC, though the number and proportion of cows culled with subclinical IMI or a history of clinical IMI also depends on the causative pathogen.

${ }_{408}$ The costs associated with subclinical and clinical IMI can be found in the 409 supplementary Tables S1, S2, and S3. 


$$
3 \mathrm{cot}
$$
et/al., 2001a; Jorgensen et al., 2016), we think that this feature is an important step in modelling IMI spread, representing both the possibility of strain specovery for subclinical cases is similarly influential on the prevalence as the transmission rate (Figure S1): with a higher probability of spontaneous recovery, the prevalence decreases.

Sensitivity analysis for the probability for a newly infected quarter to be clinical $\left(P_{c}\right.$, Table 1) showed that for $S$. agalactiae and the contagious strain of $S$. uberis an increased proportion of clinical cases leads to a decreased prevalence, while this effect was less observable in the environmental pathogens and $S$. aureus (Figure S2). Similarly, the higher the flare up probability is, the lower the prevalence becomes (Figure S3).

If the environmental part $\varepsilon$ in the opportunistic infection is increased, the prevalence increases, too, ranging from a mean of $17.8 \%$ with pure contagious infection $(\varepsilon=0)$ to a mean of 30.3 without any contagious part $(\varepsilon=1)$ after 10 years. This effect is not visible, if the prevalence is low ( $<5 \%$, Figure S4).

Reducing the number of days $d$ the opportunistic pathogen can survive in the environment showed marginal effects on model outcome, which is expected due to how the bacterial survival is weighted.

\section{Discussion}

The described model simulates a dairy cattle herd on daily basis, including the spread of IMI causing pathogens within the herd. It also includes various treatment variants for IMI, that will be investigated for cost-effectiveness in following studies. The aim of this study was to describe the model, including a new opportunistic transmission mode. With the historical view of purely contagious and purely environmental pathogens being questioned (e.g., Zadoks cific transmission properties and recent suggestions of S. agalactiae's potential opportunistic behaviour. The opportunistic transmission mode combines both contagious (via milking) and environmental transmission in one strain, as indi-

Further sensitivity analyses showed that the probability of spontaneous re- 
cated by Jorgensen et al. (2016). The contagious part of this new feature was transferred from previously already implemented contagious transmission (Halasa et al., 2009a). The environmental part represents the decay of the pathogen in the environment over time. Using an exponential function to represent the decay of infectious agents in the environment is not unusual, although slope of decline may differ for different pathogens (e.g., Whiting et al., 1996; Halasa et al., 2016). Still, implementing it for S. agalactiae should be acceptable. The infection probability depends on three main elements, in addition to the basic transmission rate; the contribution of the environment, the slope of decay, and the duration of pathogen survival in the environment. The latter has been approximated based on literature (Jorgensen et al., 2016), but the two other elements are lacking actual data from the field. We speculate that the impact of the environmental part is strain-specific, meaning that some strains are mainly found in the environment, persisting there for sometime and causing new infections, while others mainly spread via the contagious route. The weight of each mechanism is unknown, which warrants further research to assess the influence of the environment on the spread of this pathogen. Our model allows weighting of the contagious and environmental parts of pathogen spread, depending on, e.g., the strain type. Our current parameterization $(\varepsilon=0.1)$ would represent a mainly contagious spread of the pathogen with occasional transmission of IMI through the environment. This was done as an illustration of opportunistic spread in the model. In the future, the effect of the different parameters must be examined properly, when simulating the impact of control strategies against IMI caused by $S$. agalactiae.

Default values for all transmission parameters were taken from literature (Tables 1 and 2), which led to unrealistically high prevalences (Figures 2, 3, and 4). This is not surprising, as studies are usually conducted in herds with large problems or even outbreaks with the specific pathogens. In those herds, pathogen spread, and thereby the calculated transmission rates, are high. On top of that, our additional susceptibility factor $S u s c_{q}$, used to re-scale the transmission rates to include cow-specific infection, leads to higher infection proba- 


$$
\text { "x. }
$$

495

(sion

97 t

498

bilities in the model. The estimated transmission rates from the literature do not consider quarter factors, but instead they are average values for all quarters. For instance, it is known that the risk of infection is higher for quarters with previous IMI (Zadoks et al., 2001b). In order to consider the effect of these factors in the estimation of infection probability, the transmission rates are multiplied by the relative risks of quarter factors (the susceptibility factor), and hence the probability becomes artificially higher than normal. To represent a realistic situation, it therefore becomes important to rescale the transmission rates, as the quarter factors should be taken into account at the same time. Future studies estimating transmission rates should consider the effects of quarter and cow factors on the transmission rate, if possible, in order to be able to accurately model spread dynamics of IMI causing pathogens.

Our results show sensitivity of the prevalence to changes in transmission rate and other transmission parameters (see Figures $\mathrm{S} 1-\mathrm{S} 4$ ), making the use of the right parameters important. It is therefore worrisome that estimates of transmission rates are scarce and limited to few studies from few herds (e.g., Zadoks et al., 2001a, 2003; Barlow et al., 2013; Leelahapongsathon et al., 2016). Nevertheless, we decided to include a susceptibility factor and thereby cow-specific transmission in the model and adjust transmission, as studies have shown that relevant risk factors exist (e.g., Zadoks et al., 2001b). As these factors may be pertinent for management decisions regarding IMI, not including them would prevent investigating cow-specific management strategies in the future. Furthermore, as IMI causing pathogens are thought to be transmitted, among other things, during the milking process (Harmon, 1994) or through reservoirs in the environment (Zadoks et al., 2001a; Blowey and Edmondson, 2010), transmission rates are dependent on herd related factors. Considering that there are only few studies estimating these rates, and conditions are prone to change over the years, transmission rates, in the absence of proper data, will have to be adjusted in some way to model different IMI situations representing different herds or management systems. Hopefully, future research can close these gaps. Another point regarding transmission is the assumption in the model that 

527 per case cost of $€ 109$ for subclinical IMI, while our scenario 9 resulted in a median cost of about $€ 100$ per subclinical IMI case S1. In the same scenario, 529 the median cost for a clinical IMI case was around $€ 226$, which is similar to

the same transmission rate can be used for transmission to quarters of the same cow or of other cows. When transmission happens through the milking equipment, for instance, fluctuations in the milking vacuum could, depending on the milking machine's claw, lead to a reflux of milk from an infected quarter into uninfected teats (Besier et al., 2016). IMI can also be transmitted by flies (Owens et al., 1998). A fly would probably land on a quarter of the same cow before flying away, possibly leading to a higher risk of within cow spread. Given the absence of proper data to parameterize this process, the made assumption seems inevitable. Should this knowledge gap be closed in the future, different transmission probabilities could be used for within cow and between cow transmission.

Our results showed expected behavior when parameters were changed in sensitivity analyses. Different scenarios showed different prevalence patterns, e.g., in scenarios 49 and 56 (Figure 3), where the prevalence of $S$. aureus was higher when the second pathogen's prevalence was lower. In scenario 98 (Figure 4), S. agalactiae reached a higher prevalence level than in scenarios 49 or 68 (Figure 3), even though the transmission rate was the same, showing a different behavior of opportunistic transmission depending on the prevalence of other IMI pathogens. An increased total prevalence leads to more quarters having a higher risk of contracting an IMI, as history of IMI is modelled as a risk factor for new IMI. This, combined with the fact that $S$. agalactiae can build up and persist in the environment, leads to its increased incidence. The model can thus simulate different transmission behaviors of pathogens and different herds, which is necessary to investigate, e.g., how effective a treatment regimen is under different circumstances. The economic part of the model yields comparable results to other models. For instance, Steeneveld et al. (2007) found an average other studies by e.g. Halasa et al. (2009a) (€101 to €328), Huijps et al. (2008) (€164 to $€ 235)$, and Bar et al. (2008b) (€179 on average). As a substantial 

presented in this model. The model by Halasa et al. (2009a, 2010) used the same transmission framework on cow instead of quarter level, but without in560 cluding cow-specific infection and recovery. By simulating on quarter level, we

part of the costs for IMI arises from culling (Tables S1 and S2), and farmers behave differently in terms of culling (e.g., Fetrow et al., 2006), modelling herdspecific scenarios instead of average herds is also important for cost-effectiveness analyses.

Altogether, our model is able to simulate strain-, cow-, and herd-specific transmission of IMI causing pathogens on quarter level and with a daily time step. It also includes the possibility to consider different farmer priorities concerning culling by changing culling weights, or to include a prediction of the future value of a cow relative to its herd mates (Græsbøll et al., 2017) in the culling decision of the farmer, allowing a potentially more economic choice of cows to be culled. Moreover, the necessary features, to study several treatment strategies for clinical IMI and selection strategies for dry cow therapy are already implemented in the model, and further strategies or pathogen strains can be easily added. This makes it possible to simulate specific herds and investigate the cost-effectiveness of various changes to management/prevention or treatment/control strategies, both short term (operational decision making) and long term (strategic decision making), that can also be strain- and cow-specific. As different changes may be more cost-effective depending on the herd, and selective treatment decisions may be more effective when selecting the right cows to treat, it is important to include strain-, cow-, and herd-specifics in a model investigating cost-effective strategies. Simulating specific instead of average herds also means simulating diverse herd-specific disease situations, that are represented by different combinations of pathogens at different (stable) prevalence levels, which is possible with this model as shown in Figures 3 and 4.

Other bio-economic models simulating mastitis and mastitis control already exist, but to our knowledge none of the existing models combine all features exist, but to our knowledge none of the existing models combine all features allow multiple infections per cow, as this happens in reality, though one quarter can still only be infected by one pathogen or strain in our model. With this, our 

investigations into cost-effectiveness of various strain-, cow-, and herd-specific IMI prevention and control measures, while including a farmer's current strate-

model also differs from e.g. the SIMMAST model (Allore et al., 1998), which also simulates on cow level, though it does not include cow-specific recovery, and only allows infection with one pathogen at a time. The SimHerd model (Østergaard et al., 2005) allows several pathogens per cow and is cow- and herd-specific, however, cow-specific factors are only considered for infection. SimHerd's mastitis framework is based on weekly time steps and infection through a baseline risk function for all mastitis pathogens. While this is a valid approach in the setting Østergaard et al. (2005) investigated, our model can explore both constant spread and infection over time, as well as transitions between the two. In addition, modelling on quarter level is closer to the underlying biology, as IMI occurs on quarter level. By modelling the actual biological unit, IMI management can also be modelled on quarter level, e.g, drying off chronically infected quarters.

While previous models may distinguish between contagious and environmental spread, our model explicitly allows both contagious and environmental strains of the same pathogen, exemplified by $S$. uberis, and also introduces a new third opportunistic transmission type with both contagious and environmental properties, as discussed above. Furthermore, while we only included $S$. uberis with an environmental and a contagious strain to illustrate the possibility of having two strains with different transmission modes, this option should be kept in mind regarding other pathogens like e.g. S. aureus, as the model allows easy addition of other pathogens or pathogen strains. The question of which type of transmission is the right one for a particular pathogen strain cannot be answered by models, but our model allows the user to choose between the three mentioned transmission types and compare e.g. management strategies, depending on what kind of transmission is assumed for a strain. This allows gies, thereby hopefully making it easier to convince farmers to adopt proposed cost-effective changes in the future. 
Allore, H. G., Schruben, L. W., Erb, H. N., Oltenacu, P. A., 1998. Design and validation of a dynamic discrete event stochastic simulation model of mastitis control in dairy herds. Journal of Dairy Science 81 (3), 703-717.

Bar, D., Gröhn, Y. T., Bennett, G., González, R. N., Hertl, J. A., Schulte, H. F., Tauer, L. W., Welcome, F. L., Schukken, Y. H., 2008a. Effects of repeated episodes of generic clinical mastitis on mortality and culling in dairy cows. Journal of Dairy Science 91 (6), 2196-2204. 

89 (6), 1896-1905. 263-272.

Bar, D., Tauer, L. W., Bennett, G., Gonzalez, R. N., Hertl, J. A., Schukken, Y. H., Schulte, H. F., Welcome, F. L., Groehn, Y. T., 2008b. The cost of generic clinical mastitis in dairy cows as estimated by using dynamic programming. Journal of Dairy Science 91 (6), 2205-2214.

Barkema, H. W., Schukken, Y. H., Lam, T. J. G. M., Beiboer, M. L., Wilmink, H., Benedictus, G., Brand, A., 1998. Incidence of clinical mastitis in dairy herds grouped in three categories by bulk milk somatic cell counts. Journal of Dairy Science 81 (2), 411-419.

Barlow, J. W., Zadoks, R. N., Schukken, Y. H., 2013. Effect of lactation therapy on staphylococcus aureus transmission dynamics in two commercial dairy herds. BMC veterinary research 9 (1), 28.

Besier, J., Lind, O., Bruckmaier, R. M., 2016 Dynamics of teat-end vacuum during machine milking: types, causes and impacts on teat condition and udder health - a literature review. Journal of Applied Animal Research 44 (1),

Blowey, R. W., Edmondson, P., 2010. Mastitis control in dairy herds. Cabi.

Bradley, A. J., Green, M. J., 2004. The importance of the nonlactating period in the epidemiology of intramammary infection and strategies for prevention. Veterinary Clinics of North America-food Animal Practice 20 (3), 547-568.

Döpfer D., Barkema, H. W., Lam, T. J. G. M., Schukken, Y. H., Gaastra, W., 1999. Recurrent clinical mastitis caused by escherichia coli in dairy cows. Journal of Dairy Science 82 (1), 80-85.

Fetrow, J., Nordlund, K. V., Norman, H. D., 2006. Invited review: Culling: Nomenclature, definitions, and recommendations. Journal of Dairy Science

Græsbøll, K., Kirkeby, C., Nielsen, S. S., Halasa, T., Toft, N., Christiansen, L. E., 2016. Models to estimate lactation curves of milk yield and somatic cell 
Halasa, T., Nielen, M., Huirne, R. B. M., Hogeveen, H., 2009a. Stochastic bioeconomic model of bovine intramammary infection. Livestock Science 124 (1), 295-305.

671 Halasa, T., Nielen, M., van Werven, T., Hogeveen, H., 2010. A simulation model count in dairy cows at the herd level for the use in simulations and predictive models. Frontiers in Veterinary Science 3.

Græsbøll, K., Kirkeby, C., Nielsen, S. S., Halasa, T., Toft, N., Christiansen, L. E., 2017. A robust statistical model to predict the future value of the milk production of dairy cows using herd recording data. Frontiers in Veterinary Science 4.

Green, M. J., Green, L. E., Bradley, A. J., Burton, P. R., Schukken, Y. H., Medley, G. F., 2005. Prevalence and associations between bacterial isolates from dry mammary glands of dairy cows. Veterinary Record 156 (3), 71-77.

Gröhn, Y. T., Wilson, D. J., González, R. N., Hertl, J. A., Schulte, H., Bennett, G., Schukken, Y. H., 2004. Effect of pathogen-specific clinical mastitis on milk yield in dairy cows. Journal of Dairy Science 87 (10), 3358-3374.

Hagnestam-Nielsen, C., Østergaard, S., 2009. Economic impact of clinical mastitis in a dairy herd assessed by stochastic simulation using different methods to model yield losses. Animal 3 (02), 315-328.

Halasa, T., Boklund, A., Bøtner, A., Toft, N., Thulke, H.-H., 2016. Simulation of spread of african swine fever, including the effects of residues from dead animals. Frontiers in Veterinary Science 3, 6 .

Halasa, T. Huijps, K., Østerås, O., Hogeveen, H., 2007. Economic effects of bovine mastitis and mastitis management: A review. Veterinary Quarterly $29(1), 18-31$.

672 to calculate costs and benefits of dry period interventions in dairy cattle.

673 Livestock Science 129 (1), 80-87. 

nary Science 3, 90 .

Leelahapongsathon, K., Schukken, Y. H., Pinyopummintr, T., Suriyasathaporn, W., 2016. Comparison of transmission dynamics between Streptococcus uberis and Streptococcus agalactiae intramammary infections. Journal of Dairy Science 99 (2), 1418-1426. 
Steeneveld, W., van Werven, T., Barkema, H. W., Hogeveen, H., 2011. Cowspecific treatment of clinical mastitis: An economic approach. Journal of Dairy Science 94 (1), 174-188.

${ }_{27}$ Swinkels, J. M., Hogeveen, H., Zadoks, R. N., 2005a. A partial budget model Klaas, I. C., 2005. A stochastic model simulating pathogen-specific mastitis control in a dairy herd. Journal of Dairy Science 88 (12), 4243-4257.

Owens, W. E., Oliver, S. P., Gillespie, B. E., Ray, C. H., Nickerson, S. C., 1998. Role of horn flies (haematobia irritans) in staphylococcus aureus-induced mastitis in dairy heifers. American Journal of Veterinary Research 59 (9), 1122 1124.

R Core Team, 2015. R: A Language and Environment for Statistical Computing. R Foundation for Statistical Computing, Vienna, Austria. URL https://www.R-project.org/

Sargent, R. G., 2003. Verification and validation of simulation models. Proceedings of the 35th Conference, 37-48.

Schepers, A. J., Lam, T. J. G. M., Schukken, Y. H., Wilmink, J. B. M., Hanekamp, W. J. A., 1997. Estimation of variance components for somatic cell counts to determine thresholds for uninfected quarters. Journal of Dairy Science 80 (8), 1833-1840

Seegers, H., Fourichon, C., Beaudeau, F., 2003. Production effects related to mastitis and mastitis economics in dairy cattle herds. Veterinary Research $34(5), 475-491$.

Steeneveld, W., Swinkels, J., Hogeveen, H., 2007. Stochastic modelling to assess economic effects of treatment of chronic subclinical mastitis caused by Streptococcus uberis. Journal of Dairy Research 74 (4), 459-467. to estimate economic benefits of lactational treatment of subclinical staphylococcus aureus mastitis. Journal of Dairy Science 88 (12), 4273-4287.

Østergaard, S., Chagunda, M. G. G., Friggens, N. C., Bennedsgaard, T. W., 

of Dairy Science 84 (12), 2649-2663.

${ }_{755}$ Zadoks, R. N., Allore, H. G., Hagenaars, T. J., Barkema, H. W., Schukken, treatment of chronic subclinical mastitis caused by streptococcus uberis or streptococcus dysgalactiae. Journal of Dairy Research 72 (1), 75-85.

van den Borne, B. H. P., Halasa, T., van Schaik, G., Hogeveen, H., Nielen, M., 2010a. Bioeconomic modeling of lactational antimicrobial treatment of new bovine subclinical intramammary infections caused by contagious pathogens. Journal of Dairy Science 93 (9), 4034-4044.

van den Borne, B. H. P., van Schaik, G., Lam, T. J. G. M., Nielen, M., 2010b. Therapeutic effects of antimicrobial treatment during lactation of recently acquired bovine subclinical mastitis: Two linked randomized field trials. Journal of Dairy Science 93 (1), 218-233.

Whiting, R. C., Sackitey, S., Calderone, S., Merely, K., Phillips, J. G., 1996. Model for the survival of staphylococcus aureus in nongrowth environments. International Journal of Food Microbiology 31 (1-3), 231-243.

Wilson, D. J., Gonzalez, R. N., Das, H. H., 1997. Bovine mastitis pathogens in New York and Pennsylvania: Prevalence and effects on somatic cell count and milk production.Journal of Dairy Science 80 (10), 2592-2598.

Zadoks, R. N.,Allore, H. G., Barkema, H. W., Sampimon, O. C., Gröhn, Y. T., Schukken, Y. H., 2001a. Analysis of an outbreak of Streptococcus uberis mastitis. Journal of Dairy Science 84 (3), 590-599.

Zadoks, R. N., Allore, H. G., Barkema, H. W., Sampimon, O. C., Wellenberg, G. J., Gröhn, Y. T., Schukken, Y. H., 2001b. Cow- and quarter-level risk factors for Streptococcus uberis and Staphylococcus aureus mastitis. Journal Y. H., 2002. A mathematical model of Staphylococcus aureus control in dairy herds. Epidemiology and Infection 129 (02), 397-416.

Swinkels, J. M., Rooijendijk, J. G. A., Zadoks, R. N., Hogeveen, H., 2005b. Use of partial budgeting to determine the economic benefits of antibiotic 
Zadoks, R. N., Gillespie, B. E., Barkema, H. W., Sampimon, O. C., Oliver, S. P., Schukken, Y. H., 2003. Clinical, epidemiological and molecular characteristics

760 of streptococcus uberis infections in dairy herds. Epidemiology and Infection

$761 \quad 130(2), 335-349$.

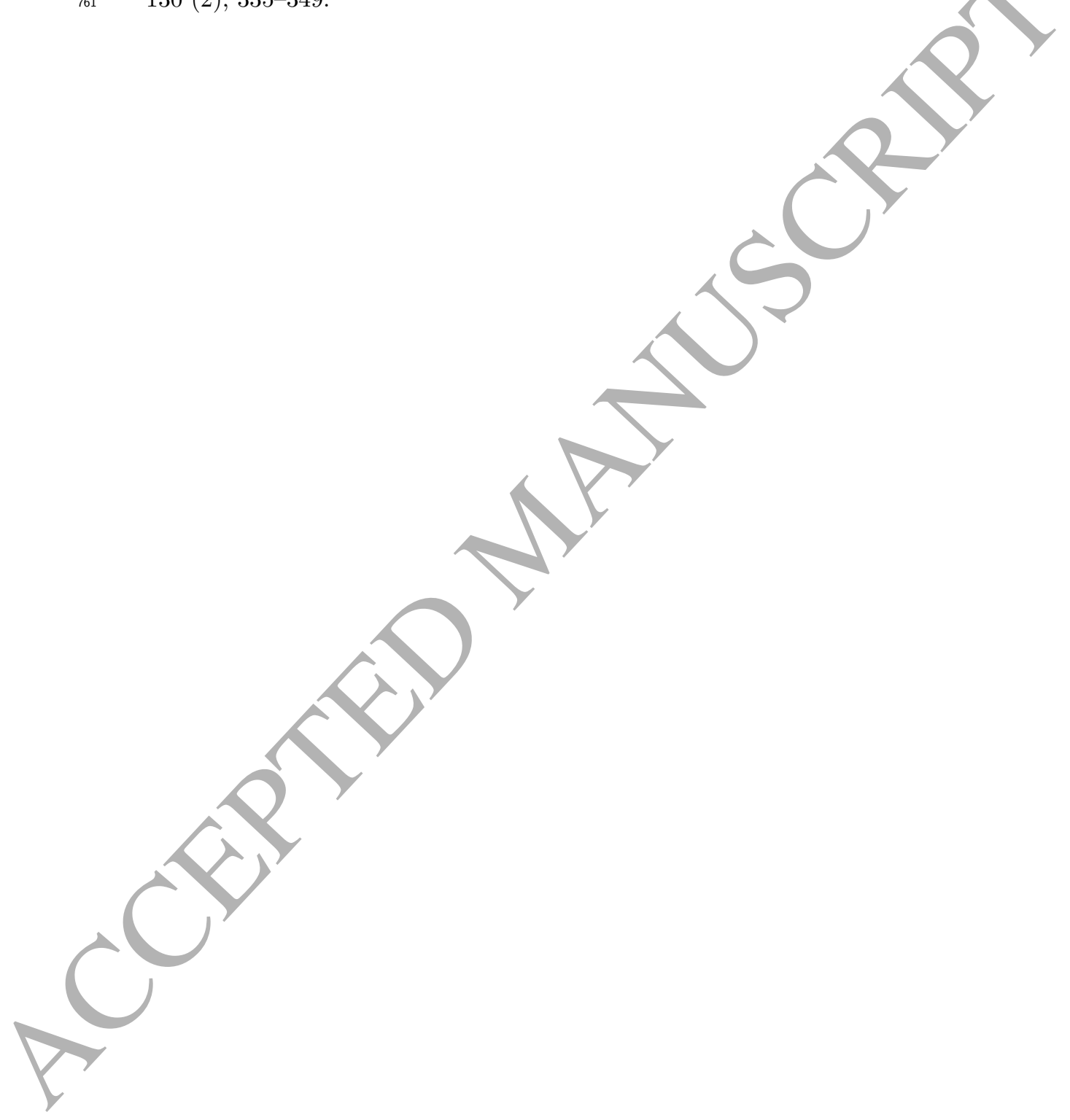

